\title{
Search for new functionality for unused objects of frame architecture
}

\author{
Denis Gavrikov*
}

Moscow State University of Civil Engineering, Yaroslavskoe shosse, 26, Moscow, 129337, Russia

\begin{abstract}
The problem of reconstruction, renovation and revitalisation of unused or abandoned framed architectural objects is one of the cases of modern sustainable development. For several such objects, complex reconstruction projects were developed during the course of four International interdisciplinary student workshops "International Building Challenge" that include the choice of new functionality. Considered Objects for renovation include the equestrian yard of the Kuznetsovs' estate in Dolgoprudny (Moscow Area, Russia), pavilion 24 of the Trekhgornaya Manufactory in Moscow, Russia, the hanging room of the Zhivopisny bridge in Moscow, Russia as well as several water towers in the Central Federal District of the Russian Federation. All mentioned objects are having at least one uniting feature: an interpretation of frame house. For the first time in Russia, mentioned student's projects reflected the real interaction of urban planners, developers, architects, designers and engineers. Projects consisted of several components: ecological (choice of materials, utilities, ecological zoning of the territory, green design standards), economic (best-use calculation), and social (needs of local residents). Empty or abandoned buildings on a frame construction basis showed functional flexibility and versatility.
\end{abstract}

\section{Introduction}

Human civilisation as we know it right now could be traced back from the dramatic change from nomadic to urban lifestyle. Since the development of the first cities in ancient Middle East, India and Mediterranean urban development never stopped and brought endless number of innovative solutions to satisfy constantly changing requirements of growing cities and its inhabitants. Arguably human societies all over the World currently live in the most fast changing environment ever and due to globalisation and inter-dependance of the cultures new development aspects may have similar or completely different solutions in different parts of the World. Historic deviations of the XX century created a unique situation in Central Russia which faced complex environmental challenge of renovation, reconstruction, revitalisation and successful reintegration of rare, empty frame buildings mainly constructed in the years of rapid industrialisation started at the second part of XIX century. Rapid infrastructure and cities development, new technologies and materials, huge number of construction projects

\footnotetext{
*Corresponding author: GavrikovDS@mgsu.ru
} 
and ideas of urban planning dated back to those days created a lot of architectural landmarks all over Russia. Further development brought to life interesting contradiction: well built and innovative to its time structures became useless and abandoned within short historic prospective - less then a hundred years. The idea to reintegrate the objects of architecture heritage into a modernity brought our project in reality.

This article dedicated to the projects focused on more narrow subject - reintegration of frame construction buildings. Naturally the European Union broad and sufficient experience in this area was considered first as frame buildings are more common on its territory comparing to Russia. In many instances Russian frame objects were incorrectly restored or renovated in the Soviet era using materials unappropriate according to the contemporary point of view, often authentic technologies used to be simplified or substituted for the sake of ease, not ecologically friendly substances were used. All the above plus often ruined conditions due to abandonment might impose serious danger to local residents. The article pays special attention to the execution of those projects with theory of architecture, urban planning and environmental design in mind.

The aim of the research is to study the accumulated materials of four consecutive international interdisciplinary workshops on the reconstruction of frame objects International Building Challenge, held in Moscow, Russia. The objectives of the study are to characterise the architectural, urban planning, interior and construction-ecological features of the renovation projects of the frame objects involved in these workshops.

\section{The scientific novelty features}

- Find and develop within the student workshops an approach towards currently abandoned/unused buildings.

- Identify sound renovation projects by combined efforts of professionals in theory of architecture, urban planning, design and civil engineering;

- Broadly evaluate for the first time ever renovation projects for currently abandoned/unused frame buildings in Central Russia through involvement of local authorities, professionals, education facilities and local residents;

- Confirm the significant functional variability of local frame buildings through modelling and experimental design;

\section{The practical novelty features}

- Involvement of experimental student projects in course of real renovation of the local architectural objects mentioned in the article;

- Methodology development for the complex renovation of abandoned/unused buildings and its incorporation into educational process via development of the guidelines for architectural design studies.

The International Building Challenge, referred here in after IBC, was originally an internship for students in the field of construction engineering at the Saxion University of Applied Sciences, where students from the Netherlands honed the skills acquired during their studies in the number of European countries: Great Britain, Belgium, France, Germany, Spain, Romania and Estonia. Since recently, the workshop started in Moscow, Russia.

This workshop became unique due to co-operation with the Saxion University of Applied Sciences and the National Association of Researchers of Timber Frame Architecture (NOIFA - the abbreviation in Russian), a co-organiser of IBC in Russia. NOIFA developed the workshop program and negotiated all the issues with the local Authorities and educational 
institutions. The role of organisers of the event was later assigned to various specialised universities in Moscow.

Few words regarding the previous publications on the International Building Challenge workshop in Moscow. One of them refers to Moscow workshop methodology and it pays special attention to the interaction of students of various specialties within one project. That never happened before. Previously in Moscow workshops related to complex renovation of historical buildings and surrounding territories only students of one or two specialties took part [1]. Another publication focuses on the IBC workshop at Moscow Architectural Institute, on the originality of the student's assignments and the nuances of the workshop methodology [2]. The third publication, made by fellow designers, noted the impact of VNIITE (All-Union Scientific Research Institute of Industrial Design, est. 1962 in the former Soviet Union and currently under integration into Russian State Technological University) design approaches on IBC [3]. In this regard, it should be noted that the Russian version of the workshop was originally developed in accordance with the educational technology of the student workshop on the reconstruction of an abandoned building in Apolda, (Germany) organised by the Bauhaus University of Weimar's History of Architecture and Monuments Protection. Thus, the novelty of this article lies in the analysis of the features of student projects through the prism of interaction of three expressive arts: design, architecture and urban planning with constructing ecology in mind.

A 'frame structure' or 'half-timbering' refers to the buildings where frames traditionally made of timber while spaces between the bearing structures called panels (in German 'Gefach' or 'Fächer') later filled-in with some kind of non-structural material (infill). The frame is often left exposed on the exterior of the building. 'Fachwerk' is a polysemic term. So, H. Müller associated the term with opus craticium and murus gallicus from the Vitruvius' tractate [4]. L. A. Serk in return uses this term to describe a large-span frame without braces and with brick filling [5]. In addition, this definition denotes a historically established construction technique, consisting of a load-bearing frame and no or almost no-load filling [6]. At the same time, especially in German version of this term, an emphasis is placed on inter-frame gaps [7], and not on the frame. Along with this, there is a non-separation of the terms 'truss' (construction) and 'half-timbered' (construction equipment) [8]. In addition, German experts may refer to 'timber frame' conical dwellings filled with clay-coated wattle (wattle and daub) or covered with skins $[9,10]$. Additionally, there are many similar regional variants of timber frame buildings, both civil and public, which are called differently in the special literature, which contradicts the scientific principle of the same name for similar phenomena.

In order to logically resolve the contradiction that arose in this review, the author proposes to shift the emphasis in the definition of frame buildings from structures and construction equipment to 'tectonics'. The term 'tectonics' in the non-visual arts is going to be used to mark the artistic interpretation of the laws of the object [11] or a construction processed plastically to achieve a certain emotional impact [12]. Based on this, in architecture in its pure form, architectural and structural systems are not used, but only plastically processed 'tectonic systems' are employed. Fachwerk can be called a tectonic system consisting of rods. This universal definition will be used in this study.

The urban development aspect of IBC is clearly based on the concept of sustainable development. A sustainable urbanised environment [13], surrounding one or another object of frame architecture considered in this article, is formed on the basis of ecological, social and economic balance. 


\section{Methods}

A new simulation technique of real interaction between the number of professionals (architects, urban planners, engineers, developers and environmental designers) was successfully tested in the framework of international interdisciplinary educational events aimed to re-purpose currently abandoned or unused frame architectural objects. Students of various specialties: architects, civil engineers and urban planners, environmental designers and developers divided into several mixed groups interacted with each other in English during weekly workshops and developed complex projects for the renovation of unique for Russia frame architectural objects. Territorial peculiarities and Green standards of both European Union and Russian Federation were taken into account on this stage. In the beginning, urban planners were concerned on functional saturation of the territory, while developers calculated the best-use of the building. Then, based on findings of the first stage, architects proposed possible functionality, and designers developed the design concepts for the premises. On the final stage, engineers made the proposals for the necessary infrastructure.

\section{Results}

For the first time, the international interdisciplinary student workshop International Building Challenge was held in Moscow and Dolgoprudny from May 7th till May 13th, 2016. It was dedicated to the renovation of the horse yard and part of the territory of the Kuznetsov merchants' estate (Mysovo) [14], which remained in municipal ownership. The equestrian building was built at the beginning of the 20th century in the Tudor-Elizabethan style and had a second timber framed floor. It was recognised as a regional monument of historical and architectural heritage. The territory of the estate has the following town planning peculiarity: it is located on the outskirts of the city and in the centre of transport communications (Vodniki railway station, Moscow Canal, Sheremetyevo airport, Likhachevskoe highway). The tourist environment of Dolgoprudny was assessed as average [15]. During the workshop the following projects were developed: a modern equestrian club (Fig. $1-\mathrm{I}-\mathrm{a}$ ), an art residence (Fig. $1-\mathrm{I}-\mathrm{c}, \mathrm{d}$ ), a cafe and a health centre (Fig. $1-\mathrm{I}-\mathrm{b}$ ).

From May 6th till May 12th 2017, the IBC interdisciplinary student workshop was held in Moscow for the second time. The aim of the workshop was to develop a concept for complex renovation and re-development of the pavilion 24 of Trekhgornaya Manufactory. The main feature of the chosen building is a unique architectural and engineering solution where metal frame and brick infill was used as an interpretation of the traditional frame construction. The building is a part of a cultural heritage site - an ensemble of the Prokhorov's Trekhgornaya Manufactory, which specialises in weaving and dyeing fabrics. The manufactory is located at the foot of the high left bank of the Moscow River, in close proximity to the White House (The House of the Government of the Russian Federation) and the World Trade Centre. It should be noted that Trekhgornaya Manufactory is the oldest Moscow textile enterprise, founded in the 18th century [16]. The unique industrial environment of Trekhgornaya Manufactory is a reserve for the rapidly developing Moscow [17]. Projects were developed for a fitness centre (Fig. 1 - II - b), a cinema, a textile museum (Fig. $1-$ II - a, c, d), and few others.

From May 14th till May 19th 2018, the workshop was held in Moscow for the third time. In 2018, this educational event was dedicated to the renovation of the Zhivopisny Bridge. The aim of the workshop was to find a new functionality for the suspended floor on the arch of the bridge and to renovate the attached territory. Structurally, this bridge is a frame interpretation. All the construction data on the Zhivopisny Bridge were kindly provided by its author, Mr. N. I. Shumakov, the President of the Union of Architects of Russia. The room 
on the arch of the Zhivopisny Bridge consequently changed the following functions: an observation deck [18], a restaurant, a wedding palace and finally became abandoned [19]. During the workshop, projects were proposed for the following purposes: an anti-cafe (Fig. 1 - III - a, b), a club, a greenhouse, and few others.

From May 13th till May 17th, 2019, the workshop was held in Moscow for the fourth time. The educational event this time was devoted to the new functionality search for water towers, reinforced with concrete frame structures. Built in the late 19th beginning of the 20th centuries those water-towers are quite noticeable objects while most of them currently unused and abandoned with few if any maintenance provided. Among the proposed new functions of those towers were the following: a museum, a cultural centre, a library and even a bathhouse. One of the project actually was to demolish the tower and clear the place for completely new construction. 


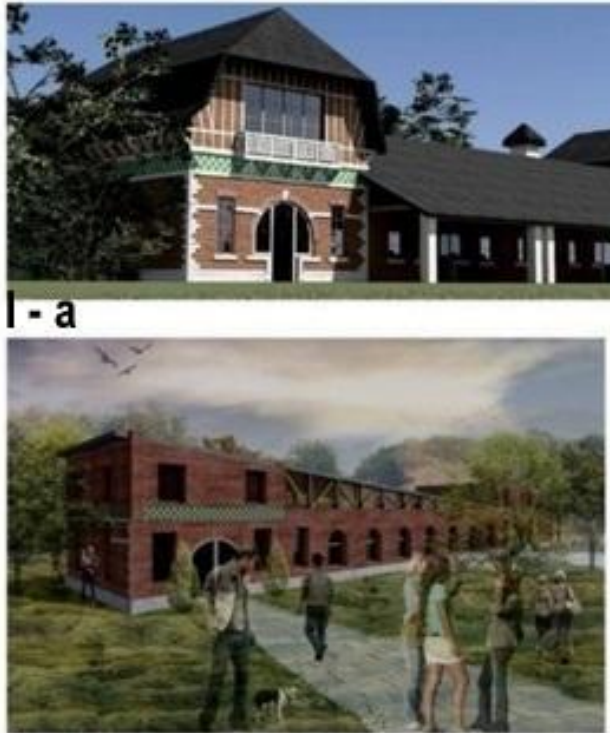

I-C

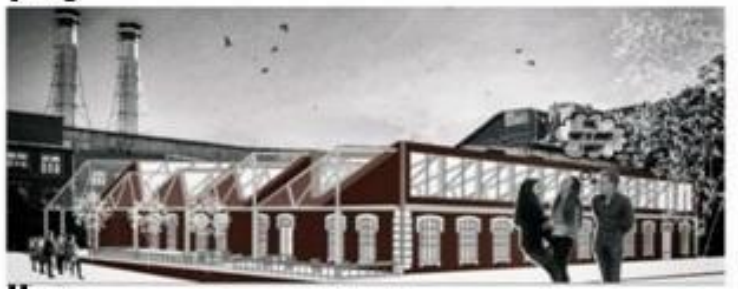

$\|-\mathbf{a}$

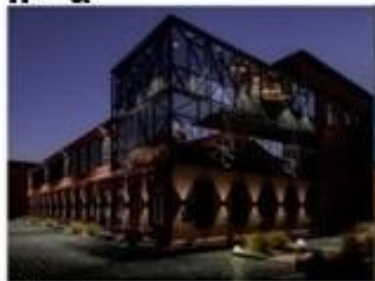

II-C

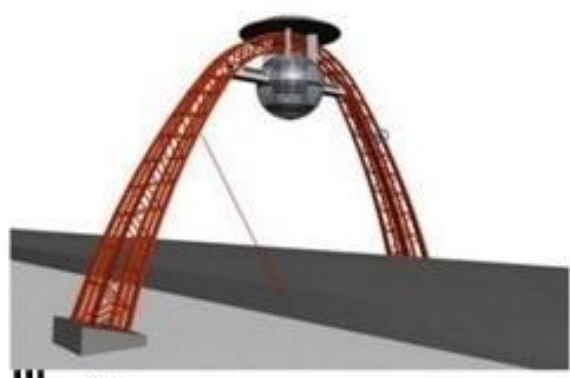

III - a

III-b

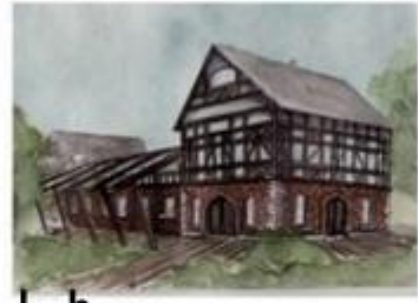

$1-b$

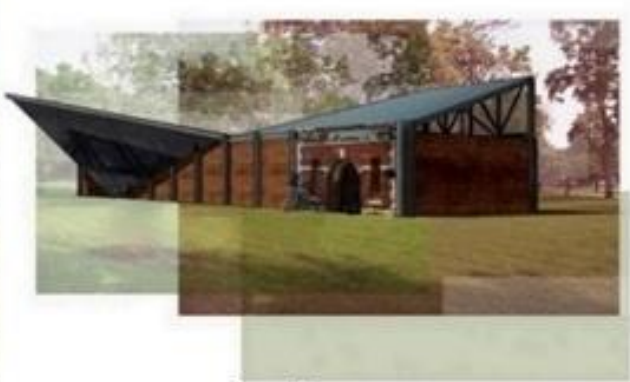

l-d

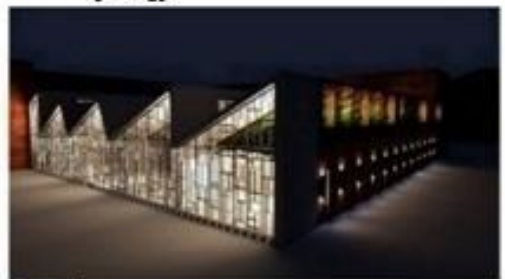

II-b
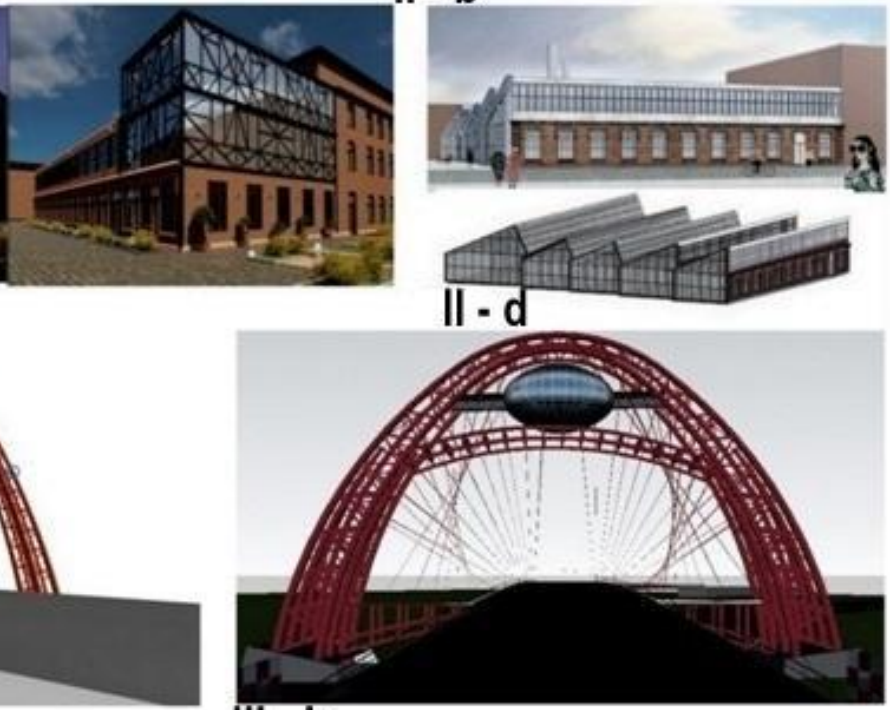

Fig. 1. Student's projects: I - Horse yard of the Kuznetsov estate in Dolgoprudny, Moscow area, Russia; II - Pavilion 24 of the Trekhgornaya Manufactory in Moscow, Russia; III Zhivopisny Bridge in Moscow, Russia. 


\section{Discussion}

The workshop International Building Challenge might certainly learn from the experience of the All-Russian workshop Point of Growth: Architectural Practices in the field of conducting surveys of residents to identify environmental shortcomings of the territories adjacent to the renovated objects [20]. Another way to obtain a more objectively justified project for the renovation of an unused architectural object is to attract specialists from the fields of tourism, advertising, and urban ecology. The third way to improve the results of future workshops should be recognised as the universalisation of its methodology by transferring it to architectural objects with a constructive basis other than frame, as it is planned to do in May 2021 in the MGSU. The fourth way to improve the results of the workshop is to combine the environmental standards of BREEAM, LEED with the green standards of Russia in the design process.

\section{Conclusions}

From the point of view of the theory of architecture and design, we can point out the functional universalism of frame tectonic systems: the wide variability of its morphology makes it easy to re-purpose the object of frame architecture. With the help of frame elements, it is easy to change the style of the facades and interiors of the building. In case of difficulties with choosing the functionality of a certain structure with a different tectonic system, it is possible to recommend adding stylish frame superstructures or extensions, which can significantly expand its functionality. From the point of view of the theory of urban planning, the territory given over for construction and located near the landmark frame object can be gentrified. From the point of view of biosphere compatibility, when renovating frame objects, it is recommended to choose modern materials with tested and recognised minimal harmful effects on the ecosystem.

The author expresses his gratitude to N. V. Danilina for the organisational efforts to conduct the workshop at MGSU. The author thanks S. V. Norenkov for attracting students from NNGASU (Nizhny Novgorod) to the workshop. The project certainly owes the aspect of territorial development to N. B. Safronova and K. B. Sivolapov. The project is obliged to V. A. Kolgashkina for the possibility of holding it at the Moscow Architectural Institute (MARHI). The appearance of the interior design aspect of the project is due to the engagements of L. A. Merkulova, A.V. Soifer, N. D. Dembich and Yu. V. Nazarov. For the presentation of the project in Russia it is necessary to thank J. C. Bazen. Tribute to the authorship of the idea and the long-term leadership of the project as a whole should be paid to G. P. Stern. Special thanks for promoting the project to E. Mikhailidi (exhibition ArchMoscow), M. Vinnik (magazine Tekhnopark), N. Tyutcheva (architectural bureau Rozhdestvenka) and J. Vershoor (Institute Neso Nuffic Russia).

\section{References}

1. G.P. Stern, J.C. Bazen, D.S. Gavrikov, Building Challenge: International education model for construction education, in proceedings of the 2nd and 3rd Regional Innovation \& Entrepreneurship Conference, 86-93, Saxion University of Applied Sciences, Enschede, The Netherlands (2016)

2. V.A. Kolgashkina, D.S. Gavrikov, Interdisciplinary student workshop International Building Challenge. Nauka, obrazovanie i eksperimentalnoe proektirovanie. Sbornik tezisov MARHI. Materialy nauchno-prakticheskoj konferencii. - MARHI 1,491-492 Moscow, Russia (2019) 
3. N.D. Dembich, E.P. Grigoryev, O.G. Jacjuk, Razvitie sistemnyh proektnyh podhodov VNIITE v sovremenny tehnologijah dizajnerskogo obrazovanija. Dekorativnoe iskusstvo $i$ prostranstvennaja sreda. Vestnik MGHPA. Moskovskaja gosudarstvennaja hudozhestvenno-promyshlennaja akademija im. S. G. Stroganova, 2-2,143-151. Moscow, Russia (2020)

4. H. Müller, Fachwerkhäuser, 13-14, Prisma-Verlag Zenner und Gürhott, Leipzig, Germany 1988)

5. L.A. Serk, Kurs architektury. Grazhdanskie $i$ promyshlennye zdanija, 2, 78 Konstruktivnye shemy $i$ elementy promyshlennogo stroitelstva, Gosudarstvennoe izdatel'stvo stroitel'noj literatury, Moscow/Leningrad, Russia (1939)

6. G.U. Großmann, H. Michels, Fachwerk als historische Bauweise. Ein Materialleitfaden und Ratgeber, 16, Anderweit Verlag Suderburg-Hösseringen, Germany (2002)

7. K. Pracht, Holzbau-Systeme: Block- und Facherkbau, Holzskelettsysteme, Gestaltung und Konstruktion, 14, Verlag Rudolf Müller, Köln-Braunsfeld, Germany (1981)

8. T. Herzog, J. Natterer, R. Schweitzer, M. Volz, W. Winter, Holzbau-Atlas. 4, pages 268269 München Institut für internationale Architektur-Dokumentation, Germany (2003)

9. M. Gerner, Fachwerk macht Schule, 15 Fulda : Arbeitsgemeinschaft Historische Fachwerstädte V., Germany (2008)

10. O. Frick, K. Knöll, U. Neumann, U. Weinbrenner, Baukostruktionslehre. - 1, 18 Springer-Verlag, Stuttgart, Germany, (2013)

11. S.V. Norenkov, Arhitektonika predmetnogo mira, 5-6, Izdatel'stvo Nizhegorodskogo universiteta, Nizhny Novgorod, Russia (1991)

12. E.S. Krasheninnikova, S.V. Norenkov, Sinarhija artefaktov tvorchestva: arhitektonika ansamblestroenija. Monografija, 62, Nizhegorodskij gosudarsrvennyj arhitekturnostroitelnyj universitet, Nizhny Novgorod, Russia (2017)

13. E.V. Shcherbina, N.V.; Danilina, Gradostroitel'nye aspekty proektirovanija ustojchivoj gorodskoj sredy. Vestnik Irkutskogo gosudarstvennogo tehnicheskogo universiteta, 11 (94) 183-186 Irkutsk, Russia (2014)

14. E.A. Ageeva, Starovery-predprinimateli Kuznecovy v kontekste russkoj zhizni vtoroj poloviny XIX - nachala XX veka. Staroobrjadchestvo v Rossii (XVII - XX vv.). Sbornik nauchnyh trudov, Jazyki slavjanskih kultur, 4, 485-501, Moscow, Russia (2010)

15. O.A. Tihonova, L.V. Senicheva, Sovremennoe sostojanie turistskoj infrastruktury $v$ gorode Dolgoprudnyj Moskovskoj oblasti. Novoe pokolenie - Moscow: 8, 214-219 Izd. S. A. Makushkin Moscow, Russia (2015)

16. L.O. Titova, Trjohgornaja manufaktura. Vchera, segodnja, zavtra. Sovremennye tendencii razvitija gorodskih sistem. Materialy Mezhdunarodnoj nauchnoj konferencii, posvjashchjonnoj 135-letiju so dnja rozhdenija osnovatelja ural'skoj arhitekturnoj shkoly, professora K. T. Babykina. Pod redakciej S. P. Postnikova, Ju. S. Jankovskoj, E. Ju. Vitjuk, 159-162 Ural'skij gosudarstvennyj arhitekturno-hudozhestvennyj universitet, Yekaterinburg, Russia (2015)

17. L.I. Pavlova, O.A. Telepnjova, Puti razvitija objekta unikalnoj promyshlennoj sredy (UPS) $v$ processe ego regeneracii (na primere fabriki Trjohgornaja manufaktura Nedvizhimost: ekonomika, upravlenie, 2, 67-71 ASV, Moscow, Russia (2017)

18. N.V. Korotin, S.E. Gorbachjov, A.V. Evseev, Podjom smotrovoj ploshchadki restorana $s$ ispolzovaniem vysokoprochnyh kanatov $i$ domkratov. Vestnik Mostostroenija, 1, 2-5 Associacija mostostroitelej, Moscow, Russia (2008) 
19. L.V. Pavlova, A.A.Pavlov, Arhitekturno-landshaftnye reshenija transportnyh sooruzhenij. Tradicii i innovacii v stroitel'stve $i$ arhitekture. Stroitel'stvo, 100-105, Samarskij gosudarstvennyj arhitekturno-stroitelny universitet, Samara, Russia (2016)

20. D.S. Gavrikov Tochka rosta - mesjac iz zhizni arhitekturnogo startapa. Tehnopark, Moscow Russia (2019) https://xn--80ajqkfgik2a.xn--p1ai/?p=1397 